\title{
The Effect of Destination Image and Risk Perception toward Decision to Visit Kampung Coklat Tourism During New Normal Covid-19
}

\author{
Nailin Nurmazidah ${ }^{1 *}$ \\ ${ }^{1}$ Departement of Management,Faculty of Economics Universitas Surabaya,Surabaya, \\ Indonesia
}

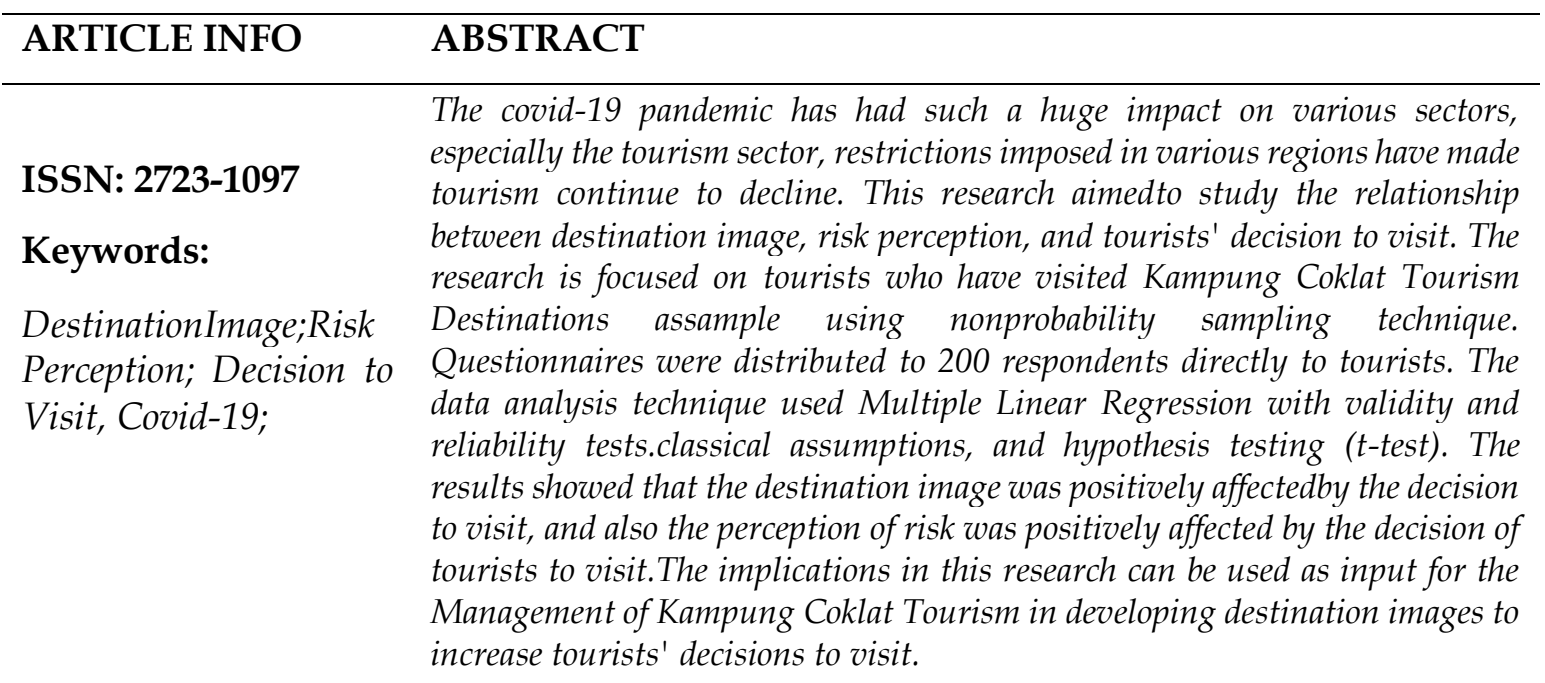

\section{Introduction}

All countries are currently facing a crisis due to a Novel Corona Virus Disease 2019 (COVID-19) Pandemic that has spread to 206 countries or regions (WHO, 2021). When COVID-19 spreads to all countries, outreach restrictions and border blocking are enforced in almost all countries and regions to reduce the number of transmission(Al Jazeera, 2020). The COVID-19 pandemic on earth has had enormous consequences, especially in the tourism sector(liputan6.com, 2020). On the other hand, the impact of the tourism sector is increasingly vital through foreign exchange earnings, regional gains, regional growth, as well as in the absorption of investment and workers as well as business development. (cnbc.com)

The COVID-19 pandemic can't be considered to have stopped, but sustainability to reduce must continue. Therefore, people must start adapting through a new lifestyle or get used to it through New Normal Life. New Normal is a change of attitude to continue conducting normal activities by adding health protocols to prevent the spread of COVID-19 (djkn.kemenkeu.go.id). During the

Journal of Businessand Management Review Vol. 2 No. 62021 Page 439-453

DOI:

*Corresponding Author

Email address: nailin.17080574027@mhs.unesa.ac.id 
New Normal COVID-19 period, it is a moment for the tourism sector to reopen which was previously forced to close due to reducing the transmission of the COVID-19 virus. Quoted from kompastravel.com, it states that there are several requirements that must be met for a permit to reopen a tourist destination/object in an area. The tourism sector can run in an area if the R0 (Basic Reproductive Number, R-Naugt) or the probability of the spread of COVID-19 is recorded below 1. In addition, there are several processes that must be conducted before the tourism object will be opened. There must be a Standard Operating Procedure (SOP), carry out a series to carry out SOPs, and initial steps (ompas.com).

Tourist visiting decisions is affected by several factors. In the opinion of Pitana and Gayatri (2005), there are several reasons that lead to the process of providing tourist policies, such as: visitor character, knowledge of the benefits of travel, insight into the destination to be visited, image of the destination, shadow of risk and uncertainty, and the potential of the destination area (Pitana and Gayatri, 2005). In general, humans conduct calculations while reviewing the types of news and examine all the risks that arise from risks before carrying out a particular action. Thus, before choosing to make a purchase, there are five processes that buyers go through during the purchase stage, namely problem identification, news search, alternative assessment, purchase policy, and post-purchase action (Pitana and Gayatri, 2005). Tourist visiting decisions are based on the concept of a buyer's purchase policy adjusted to become a tourist's visiting policy. It is inline with the research conducted by Jalilvand and Samiei (2015). It assumed that the theory of visitor visiting policy is in accordance with the buyer's purchasing policy. Based on Tjiptono (2000), visiting policy is a stage when buyers identify the problem, finding out the truth of the newsabout a particular tour and assess the extent to which each alternative can solve the problem. Furthermore, according to Swastha and Handoko (2012), visiting policy is a way of solving problems when human activities are carried out to visit a destination to fulfill their wants and needs that arise from insight into needs and desires, extracting news, evaluating alternatives of purchases, purchasing policies, and post-purchase behavior. Destination image has an impact on visitor policies to visit a tour. Before implementing a tourism policy, visitors must begin with having insight into a destination, tourist objects with positive depictions can have a greater impact on visitors to carry out visiting decisions (Agapito et al., 2013). The concept of tourism image stated by $\underline{\text { Chi et al., }}$ (2018), the definition of Destination Image is a collection of connections related to a destination in the minds of consumers. Meanwhile, Destination Image, according to Liu et al., (2018) are several judgments, beliefs, thoughts, assumptions, and emotions that are manifested from time to time leading to a tourist destination. There are 3 dimensions in the destination image; cognitive, affective, and conative (Agapito et al., 2013). Based on Tasci and Kozak (2006), Tourism image is quite vital when it causes individuals to carry out tourism. Several previous researchers have proven that destination image has a positive impact and has a significant impact on visiting decisions. According to research by $\underline{\mathrm{Chi} \text { et al., (2018) }}$ and $\underline{\mathrm{Chi} \& \mathrm{Qu}(2008)}$, 
destination image has a positive effect on visiting decisions. Furthermore, Damarsiwi \& Wagini (2018) stated that the Destination Image had a positive and significant impact on the Visiting policy. However, this research did not side with the research of Suwarduki et al., (2016) stating that the image of the destination does not have an impact on travel policy.

Tourist travel policies are not only caused by destination image, but it can also be affected by the perception of the risks in the destination. Based on Reisinger \& Mavondo, (2005), before deciding to visit, tourists first consider the risks that may be obtained while visiting a tourist destination (Reisinger \& Mavondo, 2005). Besides, according to Reichel et al., (2007), visitors usually tend to explore tourist objects that have small risks. Destination objects with high risks tend to be avoided by visitors. Some of the reasons that are considered to be a vital risk in the tourism sector are as follows: Opinion of Seddighi \& Theocharous (2002) the reason that is considered to be a vital risk in the tourism world is a situation of chaos and political instability. Based on Miller \& Ritchie(2003) Health issues are the main risks in the world of tourism. Meanwhile, McKercher \& Wong, (2004) argued that the level of crime and natural disasters are the main risk factors in the world of tourism. Besides, there are also other risks that affect the world of tourism such as risk of facilities, finances, objects, psychological, emotional, social, and time reasons (Weber \& Roehl, 2001). Previous research has proven that risk perception significantly affected visiting decisions. Reichel et al., (2007) stated that risk perception has a significant effect on visiting decisions.

East Java Province has a high total number of tourists in Indonesia. In 2018, East Java took the first position as a province frequently visited by tourists (kompas.com). Based on the data from the Central Statistics Agency (BPS 2018), the province of East Java was recorded to have the highest tourist visit rate of 15,681,166 visits. While in 2019, the number of visits had increased to 16,216,155 visits (jatimbps.go.id ). Blitar Regency is one of the leading regencies for East Java tourism (disparbudpora.blitarkab.go.id). Blitar Regency has tourism destination resources that can be optimized and also has the potential to be optimized in the future. It means that there are various types of destination objects that have the main attraction. Besides destination objects in Blitar Regency can also collaborate with destinations in other districts such as Kediri Regency, Blitar City and Malang Regency (blitarkab.go.id). Based on data from disparbudpora.blitarkab.go.id, Blitar Regency has several tourism categories including historical destinations, natural destinations, recreational destinations, cultural destinations and artificial destinations. In 2018, Blitar Regency managed to obtain an award at the East Java Tourism Award for the best artificial tourism category that was won by Kampung Coklat Tourism(disparbupora.blitarkab.go.id).

Kampung Coklat is a priority educational tours from Blitar Regency.This tourist attraction is identical to family tourism(Kampung Coklat.com). Besides an educational tourist spot, Kampung CoklatBlitar has also become the largest cocoa 
cultivation object in East Java Province. Educational Tourism of Kampung Coklatin Blitar is quite unique because it utilizes warehouses and gardens as tourist attractions (Blitarkab.go.id). Kampung Coklat is a destination object that has enhancement in the number of tourists during the New Normal COVID-19. Quoted from Lentera.com, the increase in the number of visitors to the Kampung Coklat Tourism Destination was caused due to the village of chocolate applied a unique concept, namely traveling while educating about COVID-19. Besides, the Kampung Coklat also prepare 19 special Task Forces for supervising, reminding and explaining to the publicvisitors who have not complied with health protocols.

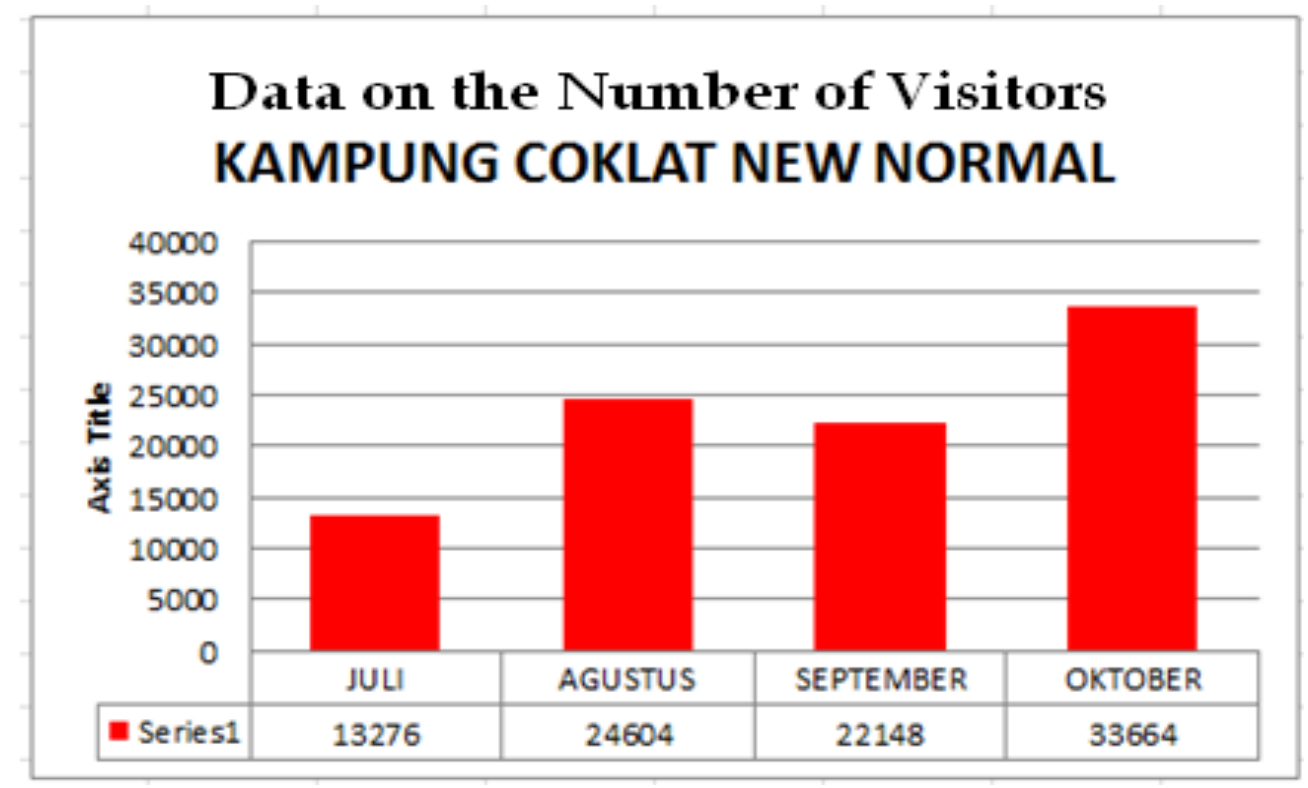

Figure1.Data on the Number of Visitors to Kampung Coklat 2020

Figure 1 shows the graph of the number of visitors to Kampung Coklat from July to October.The graph explains that on average, there was an increase in total visitors each month, in July of 13276 visitors.In August, the total visitors increased to 24604 visitors. Next, in September, the total visitors decreased to 22148 visitors. In October, the total return visitors continued to increase to 33664 visitors.

From the graphic explanation of the number of visitors above, it can be seen that there had been a gap phenomenon between theory and reality. The difference is in the theory stating that in general, visitors tend to explore destination objects that had little risk (Reichel et al., 2007). In this case, the risk in question was the risk related to the transmission of the COVID-19 Virus, considering that we are currently still in the pandemic period. This situation is in contrast to the total visitors to Kampung Coklat that should have decreased due to the risks that might be caused, but the total visitors on average have increased every month during the new normal period of COVID-19.This 
research aimed to find out the impact of destination image and perceived risk on the decision to visit.

\section{Literature Review}

\section{Decision to Visit}

Tourist decision to visitis based on the concept of buyer purchasing decisions adjusted to become tourist visiting policies, for example research conducted by Doosti et al., (2016) that interpreted the theory of visitor visiting decisions in accordance with buyers' purchasing decisions. Based on Tjiptono (2008), the purchase decision is a stage when the buyer knows the problem, finds the fact of news about certain goods or brands and assesses the extent to which each alternative can solve the problem.Then,it leads to a purchase decision. Next, Suharno dan Yudi Sutarso, (2010) defined purchasing decisions as a process when consumers have made their choices and make purchases of goods, also consume them. Then according to Swastha and Handoko (2012), purchasing decisions are a way of solving problems in human activities to buying an object or service to satisfy needs and wants that are formed from the identification of wants and needs, extracting news, evaluating purchasing alternatives, purchasing policies, and postpurchase behavior in order to measure the variables of visiting decisions using indications from Nuraeni et al., (2015)Javed et al., (2020) such as: Value For Money (What Travelers Get Compared With The Cost), Comfort During The Holiday, Destination Amenities and Environmental Features, Destination Attraction and Tourists Personal Traits.

\section{Destination Image}

Destination image is a collection of memories and perceptions that are still in the minds of tourists (Hidayah, 2019). Furthermore, according to Becken et al., (2017) The image of tourist destinations is defined as the image of tourism products connected to destination objects and tourist facilities, that can directly meet the wishes of visitors. Furthermore, according to Chi et al., (2018) the definition of Destination Image is a collection of connections related to a destination in the minds of consumers. While the Destination Image according to Liu et al., (2018) there are several assessments, beliefs, mindsets, perceptions, and emotions realized from period to period towards a tourist attraction.

In the destination image, there are 3 dimensions of the destination image, such as cognitive, affective and conative images (Agapito, et al., 2013).Image of Cognitive Destinations refers more to one's insight and rational thoughts such as quality, friendliness of residents, attractions, weather and prices. Furthermore, the Affective Destination Image refers to a person's imagination, hopes and thoughts that are more emotional about a place. The last is Conative Destination Image as combination of cognitive Destination Image and Affective Destination Image, in 
which in determining the destination, the information obtained is used. In this research, the tourism destination image indicator adopted from the research of Chi \& Qu (2008) and Chi et al., (2018), and adapted to the research object as follows: Environment, Infrastructure, Accessibility and Price. This destination is in accordance with "my personality" and lastly "My friends will think of me very much if I visit this destination".

Based on Hidayah, (2019), the image of a destination image by visitors can affectan individual in deciding to visit the destination. This research encourages previous research conducted by Damarsiwi \& Wagini (2018), Mohaidin et al., (2017), Chi et al., (2018) and Chi \& Qu (2008). They stated that Destination Image has an impact on Visiting Decisions. However, this research did not encourage the results of research from Suwarduki et al., (2016) stating Destination Image did not have a significant impact on Visiting Decisions. This is because there are differences in the research of Suwarduki et al., (2016), the difference is in the with Indonesian tourism objects using Instagram users as respondents. Thus, the initial hypothesis given in this research is:

H1: There is a positive effect of destination image on decision to visit

\section{Risk Perception}

Based on Suryani(2008), perceived risk can be interpreted as ambiguity that is accepted by buyers when they can't review the opportunities that can be faced from the purchasing policy implemented. Featherman \& Pavlou (2003) in general defined risk perception as the possibility of loss or loss when obtaining a result. A similar opinion is expressed by Tavitiyaman \& Qu, (2013) who defined risk perception as the buyer's perception of the uncertainty of the bad consequences that will occur on the consumption of an item or service.

Based on Seddighi \& Theocharous (2002), the factors that are considered the main risks in the world of tourism are conditions of war and political instability. According to Miller \& Ritchie (2003)Health issues are the main risk in the world of tourism.Meanwhile, McKercher \& Wong (2004) argued that crime rates and natural disasters are major risk factors in tourism. In addition, there are also other risks that affect the world of tourism such as equipment risk, financial, physical, psychological factors, satisfaction, social, and time (Weber \& Roehl, 2001). To measure Risk Perception using research indicators by Rocklöv et al., (2016) also Malik et al. (2018) as follows: Health, Anxiety, Safety and security.

Based on Reisinger \& Mavondo, (2005) before deciding to visit, first,tourists consider the risks that may be obtained when visiting a destination. This research encourages a number of previous studies, such as the research of Reichel et al., (2007), Pizam \& Fleischer, (2002), Rittichainuwat \& Chakraborty (2009), Reisinger 
\& Mavondo, (2005) stated that risk perception had a significant effect on visiting decisions. The second hypothesis of this research is:

$\mathrm{H} 2$ : There is a positive effect of risk perception on visiting decisions

\section{Method}

This research used quantitative methods with the type of conclusive research to find specific hypotheses and examine specific correlations from the data that had been obtained, then analyzed quantitatively (Malhotra, 2017). Research data used primary data obtained through the results of respondents' answers. Secondary data were obtained through literature study that was used to complement primary data. The population in this research was infinity. The characteristics of the respondent werepeople who had come to Kampung Coklat Tourism Destinations, and aged 1560 years. The sample in this research was 200 respondents, and used a nonprobability sampling method with judgmental sampling technique according to the characteristics of the respondents. The data collection technique was conducted using a research instrument in the form of an offline questionnaire that was distributed directly to visitors to the Kampung Coklat Tourism Destination. This research used multiple linear regression.

\section{Result and Discussion}

\section{Characteristic of Respondent}

Characteristics of the respondents in this research were based on demographic factors such as gender, age and occupation of the visitors to Kampung Brown Tourism Destinations that were adjusted using the results of the questionnaire that had been distributed by the researchers. Respondents in this research were visitors who have visited to Kampung Coklat Tourism Destinations at least 1 time with the age of 15-60 years. Based on the results of the distribution of the offline questionnaire, data on the demographic characteristics of the respondents in this research were obtained that the characteristics of respondents according to sex, it was dominated by female respondents of 113 respondents or $56 \%$. Then the characteristics of respondents based on age was dominated by respondents aged 15-30 years of 133 respondents or $67 \%$. Furthermore, the category of respondents according to profession, it was dominated by student of 105 respondents or $53 \%$. Characteristics of respondents according to income were dominated by respondents with an income of $<500,000$ of 114 respondents or $57 \%$,

\section{Model Feasibility Test}

Based on the results of the discussion of the effect of Destination Image and Risk Perception on Decisions to Visit Kampung Chocolate Tourism Destinations, the values of R (correlation) and R2 (coefficient of determination) are as follows: 
Table 1. Correlation Value and Coefficient of Determination

\begin{tabular}{ll|r|r|r}
\hline Model & $\mathrm{R}$ & \multicolumn{1}{c}{$\mathrm{R}$} & \multicolumn{1}{c}{$\begin{array}{c}\text { Adjusted R } \\
\text { Square }\end{array}$} & $\begin{array}{c}\text { Std. Error of the } \\
\text { Estimate }\end{array}$ \\
\hline 1 &, $606^{\mathrm{a}}$ &, 367 &, 360 & 2,90274 \\
\hline
\end{tabular}

a. Predictors: (Constant), Risk Perception, Destination Image

b. Dependent Variable: Decision to Visit

Sources : IBM SPSS Statistics 26

Based on table 2, it can be explained that the contribution value or adjusted R2 value for the independent variable, namely Destination Image (X1) and Risk Perception (X2) on the dependent variable, namely Visiting Decision (Y) is 0.360 or $36 \%$. That is, Destination Image (X1) and Risk Perception (X2) (have a proportion of influence on Visiting Decisions by $36 \%$ while the remaining $64 \%$ or 0.640 is influenced by other variables that are not included in the linear regression model.

\section{Result of Hypothesis Test}

In a research, hypothesis testing was conducted to determine the dominant independent variable affecting the dependent variable. To determine the relation between the independent variable and the dependent variable, it can be seen from the significance value, the significance level (a) in this research was 0.05 . If the significance value was $<0.05 \mathrm{TO}$ the independent variable was declared to have a significant impact on the dependent variable, and if the significance value was $>0.05$ then the independent variable had no impact on the dependent variable. Acceptance or rejection of a hypothesis could be conducted by comparing the value of tcount with t-table.

Table 2.Result of Hypothesis Test

\begin{tabular}{|c|c|c|c|c|c|}
\hline & \multirow{2}{*}{ Model } & \multicolumn{2}{|c|}{ Unstandardized Coefficients } & \multirow[t]{2}{*}{$\mathrm{t}$} & \multirow[t]{2}{*}{ Sig. } \\
\hline & & B & Std. Error & & \\
\hline \multirow[t]{3}{*}{1} & (Constant) & 15,874 & 1,812 & 8,76 & 0 \\
\hline & $\begin{array}{l}\text { Destination } \\
\text { Image }\end{array}$ & 0,334 & 0,051 & 6,606 & 0 \\
\hline & $\begin{array}{l}\text { Risk } \\
\text { Perception }\end{array}$ & 0,211 & 0,052 & 4,016 & 0 \\
\hline
\end{tabular}

Source: SPSS 26.0Output, processed data.

Based on table 2, the results of $\mathrm{H} 1$ and $\mathrm{H} 2$ are accepted. The results of testing the first hypothesis (H1) showed the results of the $t_{\text {count }} X 16.606>t_{\text {table }} 1.65$ and a significance value of $0.020<0.05$ until $\mathrm{H} 0$ was rejected and H1 was accepted. Furthermore, the destination image variable had a significant impact on the decision to visit. The second test hypothesis $(\mathrm{H} 2)$ showed the results of $\mathrm{t}_{\text {count }}$ of 4.106 $>t_{\text {table }}$ of 1.65 and a significance value of $0.000<0.05$. Furthermore, $\mathrm{H} 0$ was rejected 
and $\mathrm{H} 2$ was accepted. Next, the risk perception variable had a significant impact toward the decision to visit.

\section{The Effect of Destination Image (XI) toward Decision to Visit (Y)}

The results of this research indicated that there was a significant effect between Destination Image on Decision to Visit. It means that the better the Destination Image of the Kampung Coklat Tourism Destination, the better impact on the Decision to Visit the Kampung Coklat Tourism Destination. because a factor that affects the decision to visit is the image of the destination. Thus, this proves the theory put forward by Hidayah (2019) suggesting that Destination Image is one of the causes that can have an impact on Decision to Visit.

This research supportws previous research from Damarsiwi \& Wagini, (2018), Mohaidin et al., (2017), Chi et al., (2018) and Chi \& Qu (2008) stating that that Destination Image had an effect on Decision to Visit. However, this study dis not support the results of research from Suwarduki et al., (2016) stating that Destination Image had no significant impact on Visiting Decisions. This was probably due to differences in the object of research. In Suwarduki et al., (2016) Indonesian tourism objects usedInstagram users as respondents.

Thedestination image in this research was measured using 4 indicators, there were environment, infrastructure, accessibility, and price. the environment of the Kampung Coklat tourist destination was safe. The environment of the Kampung Coklat tourist destination is clean.There was a variety of food choices in the Kampung Coklat tourist destination. There were also various accommodation options in the Kampung Coklat tourist destination. There was aneasy access roads to the Kampung Coklat tourist destination, the availability of a large parking lot at the destination Kampung Coklat tourism. Entrance ticket prices was cheap, food prices were affordable, Kampung Chocolate tourist destinations according to my personality, my friends will think of me when I visit Kampung Chocolate tourist destinations. Based on the respondents' answers to environmental indicators, there were three items that have the highest average answers, such as "the environment of the Kampung Coklat tourist destination is safe" then "the environment of the Kampung Coklat tourist destination is clean" and "there are various places of choice for food in the Kampung Coklat tourist destination"

The first statement was "Environment of Kampung Coklat is safe "This statement obtained an average score of 4.47 through the strongly agree group. It proves that most respondents agreed that the Kampung Coklat Tourism Destination environment is safe. This can be proven by the commitment of Kampung Coklat to maintain the safety of visitors when visiting the Kampung Coklat Tourism Destination by installing many CCTVs at various points in the Kampung Coklat Tourism Destination environment. Besides, in Kampung Coklat tourist area, security officers were also alerted to monitor visitors. Therefore, the statement that the village environment was safe was very relevant to the actual state of the Kampung Coklat Tourism Destination. Female respondents with an age range of 15-30 years dominated this research. When related to the results of female 
respondents aged 15-30 years, they tended to choose safe destinations for themselves and their families considering that Kampung Coklat Tourism Destinations are family educational tours so that the safety factor played a very important role in affecting the decision to visit.

For the second statement "Kampung Coklat Tourism Destination Environment is clean". This statement had an average score of 4.47 with the group strongly agree.It proves that most respondents agreed that the Kampung Coklat Tourism Destination environment was clean. This proves that most of the respondents agreed that the environment in the village was clean. This can be evidenced by the commitment of Kampung Coklat to maintain cleanliness in the Kampung Chocolate Tourism Destination environment by alerting janitors at various points of the Kampung Chocolate Tourism Destination. In addition to various slogans to maintain cleanliness such as throwing garbage in its place that is installed in almost all points at the Kampung Coklat was a reminder for visitors to always maintain cleanliness. Therefore, the statement that the Kampung Coklat environment was clean,was very relevant to the actual state of the Kampung Chocolate Tourism Destination. Female respondents with an age range of 15-30 years dominated in this study. When related to the results of female respondents who were 15-30 years old and work as students or college students tend to choose clean destinations. Destination cleanliness was a factor that is very concerned by tourists, especially female tourists.It is because destinations with good hygiene tend to make tourists feel comfortable. Therefore, cleanliness is a factor that can affect tourists to visit the Kampung Coklat Tourism Destinations.

For the third statement, it was "There are choice of food inKampung Coklat Tourism Destination". In this statement, it has an average value of 4.47 with the group strongly agree. This proves that most of the respondents agree that there are places of choice of food at the Kampung Coklat Tourism Destination. This is evidenced by the many food stands available at the Kampung Coklat Tourism Destination that sold various menu options at various prices. Thus, visitors would have many choices when they would consume food in the Kampung Coklat Tourism Destination environment. Therefore, the statement that there is a choice of food places at the Kampung Coklat Tourism Destination was very relevant to the actual situation of the Kampung. Female respondents with an age range of 15-30 years dominated this research. When related to the results of female respondents aged 15-30 years and having an income of $<500,000$, they tended to choose destinations that have a variety of food choices. This was useful for budget adjustments. Besides, the availability of various food choices also serves to meet the different tastes of visitors. Thus, the availability of food choices at the Kampung Coklat Tourism Destination was an important factor in affecting the decision to visit.

\section{Effect of Risk Perception (X2) toward Decision to Visit (Y)}

The research output concluded that there was a significant effect between the Assumption of Risk on the Visiting Policy. This means that if the perception of 
risk was high, it would affect the decision to visit, because one of the factors that affect the decision to visit is the perception of risk. Thus, it proves the theory put forward by Suryani (2008) stating that Risk Perception affects Visiting Decisions.

The results of this research supported several previous studies such as research conducted by Reichel et al., (2007), Pizam \& Fleischer (2002), Rittichainuwat \& Chakraborty (2009), Reisinger \& Mavondo(2005). They stated that that risk perception has a significant effect on decision to visit.

Measuring the perception of risk used 4 indicators, there were health, anxiety, safety and security. I visited the Kampung Coklat tourist destination during the COVID-19 pandemic because I wasn't worried about contracting other health risks, I visited the Kampung Coklat tourist destination during the COVID-19 pandemic because I wasn't worried about the risk of physical or psychological dependence, I wasn't afraid to visit at the Kampung Coklat tourist destination during the COVID-19 pandemic, I prioritize personal safety while visiting the Kampung Brown tourist destination during the COVID-19 pandemic, I will change the decision to visit the Kampung Chocolate tourist destination if there is a risk of spreading the COVID-19 virus. If there is a high risk of the COVID-19 virus, I will postpone visits to the Kampung Chocolate tourist destination. From the statement items, the highest score was "I will postpone a visit to the Kampung Coklat tourist destination if there is a high risk of the COVID-19 virus" with an average value of 4.37. It means that the average respondent strongly agreed that they will Postpone to visit Kampung Coklat Tourism Destinations if there is a high risk of spreading the COVID-19 virus. With the high risk of transmitting the virus, it will make tourists prioritize personal safety by delaying the decision to visit the Kampung Coklat Tourism Destinations. When related to the results of female respondents aged 15-30 years, they tended to delay visits when there was a high risk of transmission from the COVID-19 virus, this is because females tend to have overthinking so that they will prefer to postpone visits than accept the risk of transmitting the COVID-19 virus.

\section{Conclusion}

Based on the output of research and discussion that has been conducted, it can be stated that there is a positive and significant impact between the value of the destination (destination image) on the decision to visit, and there is a positive and significant effect on the perception of risk on the decision to visit in Kampung Coklat Tourism Destinations. In this research, there are several things that make limitations, there are: offline questionnaire distribution takes a long time. In addition, this research did not provide an open questionnaire so that the discussion on Destination Image, Risk Perception and Visiting Decisions was less in-depth.

For the practical implications of the results of this research, Kampung Coklat Management is expected to continue to maintain or even improve the cleanliness 
and safety of the Kampung Coklat Tourism Destination area, in addition to adding various rides and facilities. It can also be conducted in order to attract tourists to visit the Kampung Chocolate Tourism Destinations, such as adding development of rides for games, addition of public facilities such as bathrooms. Besides, Kampung Coklat Management must also be disciplined in implementing the health protocol to reduce thspread of the COVID-19 virus. This aims to maintain the perception of risk from tourists so that tourists are not afraid to visit the Kampung Coklat Tourism Destinations. While the theoretical implication find that the destination image variable has the greatest effectcompared to risk perception. If the destination image increases, it will increase the decision to visit Kampung Coklat.

\section{References}

Agapito, D., Oom do Valle, P., \& da Costa Mendes, J. (2013). The CognitiveAffective-Conative Model of Destination Image: A Confirmatory Analysis. Journal of Travel and Tourism Marketing, 30(5), 471-481. https:/ / doi.org/10.1080/10548408.2013.803393

Al Jazeera. (2020). 2020: A Year in Review. Al Jazeera. https://www.aljazeera.com/news/2020/12/31/2020-a-year-in-review

Becken, S., Jin, X., Zhang, C., \& Gao, J. (2017). Urban air pollution in China: destination image and risk perceptions. Journal of Sustainable Tourism, 25(1), 130-147. https:/ / doi.org/10.1080/09669582.2016.1177067

Blitarkab.go.id. (2016). Kampung Coklat. Blitarkab.Go.Id. https:/ / www.blitarkab.go.id/2016/05/15/kampung-coklat/

Damarsiwi, E. P. M., \& Wagini, W. (2018). Pengaruh Electronic Worth Of Mouth dan Citra Destinasi Terhadap Keputusan Berkunjung Wisatawan Ke Pulau Tikus. Seminar Nasional Royal (SENAR), 9986(September 2018), 479-484.

Chi, Qing-Christina Gengdan Qu, Hailin. 2008. Examining the structural relationships of destination image, tourist satisfication and destination loyalty: An integrated approach Science Direct Tourism Managemen

cnbcindonesia.com. (2020). Saat Ekonomi Bangkit dari Corona, Pariwisata Masih Menderita.

Cnbcindonesia.Com. https:/ / www.cnbcindonesia.com/market/20200619113525-17-166548/ saatekonomi-bangkit-dari-corona-pariwisata-masih-menderita

disparbupora.blitarkab.go.id. (2019). Kabupaten Blitar Raih 3 Penghargaan Anugrah Wisata Jawa Timur. Disparbupora.Blitarkab.Go.Id. https:/ / disparbudpora.blitarkab.go.id/kabupaten-blitar-raih-tigapenghargaan-anugerah-wisata-jawa-timur-pada-east-java-culture-andtourism-award-2019/

djkn.kemenkeu.go.id. (2020). New Normal di Tengah Pandemi Covid-19. Djkn.Kemenkeu.Go.Id. djkn.kemenkeu.go.id

Doosti, S., Jalilvand, M. R., Asadi, A., Khazaei Pool, J., \& Mehrani Adl, P. (2016). Analyzing the influence of electronic word of mouth on visit intention: the 
mediating role of tourists' attitude and city image. International Journal of Tourism Cities, 2(2), 137-148. https:/ / doi.org/10.1108/IJTC-12-2015-0031

Featherman, M. S., \& Pavlou, P. A. (2003). Predicting e-services adoption: A perceived risk facets perspective. International Journal of Human Computer Studies, 59(4), 451-474. https:/ / doi.org/10.1016/S1071-5819(03)00111-3

Hidayah. (2019). Pemasaran Destinasi Wisata (Edisi Pert). Alfabeta.

jatim.bps.go.id. (2020). Kunjungan Wisatawan Mancanegara ke Jawa Timur melalui Juanda pada bulan Agustus 2019 naik sebesar 18,33 persen. Jatim.Bps.Go.Id. https:/ /jatim.bps.go.id/pressrelease/2019/10/01/1037/kunjunganwisatawan-mancanegara-ke-jawa-timur-melalui-juanda-pada-bulan-agustus2019-naik-sebesar-18-33-persen.html

Javed, S. A., Ikram, M., Tao, L., \& Liu, S. (2020). Forecasting key indicators of China's inbound and outbound tourism: optimistic-pessimistic method. Grey Systems: Theory and Application, 11(2), 265-287. https://doi.org/10.1108/gs-12-20190064

Kampung Coklat.com. (2020). Wisata Edukasi Kampung Coklat. Https://Kampung Coklat.Com/. https:/ / Kampung Coklat.com/

Kompas.com. (2020). Pariwisata Dibuka Saat Pandemi, Ini Syarat Hingga Protokol Kesehatan Yang Harus Dipenuhi. Kompas.Com. https:/ / nasional.kompas.com/read/2020/06/23/12215801/pariwisata-

kompaspedia.com. (2020). Provinsi Jawa Timur Menjadi Pusat Kegiatan Ekonomi Sekaligus Pintu Gerbang Aktivitas Bagi Penduduk Indonesia Bagian Timur. Kompaspedia.Com. dibuka-saat-pandemi-ini-syarat-hingga-protokolkesehatan-yang?page $=$ all

liputan6.com. (2020). Sektor Pariwisata Nyaris Tumbang Akibat Corona Covid-19, Menparekraf Masih Siapkan Solusi. Liputan6.Com.https://www.liputan6.com/lifestyle/read/4209455/sektorpariwisata-nyaris-tumbang-akibat-corona-covid-19-menparekraf-masihsiapkan-solusi

Liu, H., Li, X. (Robert), Cárdenas, D. A., \& Yang, Y. (2018). Perceived cultural distance and international destination choice: The role of destination familiarity, geographic distance, and cultural motivation. Journal of Destination Marketing and Management, 9(February), 300-309. https:/ / doi.org/10.1016/j.jdmm.2018.03.002

Malhotra, N. K. (2017). Riset Pemasaran (Edisi Keem). PT Indeks Kelompok Gramedia.

Malik, O. F., Schat, A. C. H., Raziq, M. M., Shahzad, A., \& Khan, M. (2018). Relationships between perceived risk of terrorism, fear, and avoidance behaviors among Pakistani university students: A multigroup study. Personality and Individual Differences, 124(November 2017), 39-44. https://doi.org/10.1016/j.paid.2017.11.044

McKercher, B., \& Wong, D. Y. Y. (2004). Understanding tourism behavior: Examining the combined effects of prior visitation history and destination status. Journal of Travel Research, 43(2), 171-179. 
https:/ / doi.org/10.1177/0047287504268246

Miller, G. A., \& Ritchie, B. W. (2003). A farming crisis or a tourism disaster? An analysis of the foot and mouth disease in the UK. Current Issues in Tourism, 6(2), 150-171. https:// doi.org/10.1080/13683500308667949

Mohaidin, Z., Wei, K. T., \& Ali Murshid, M. (2017). Factors influencing the tourists' intention to select sustainable tourism destination: a case study of Penang, Malaysia. International Journal of Tourism Cities, 3(4), 442-465. https:/ / doi.org/10.1108/IJTC-11-2016-0049

Nuraeni, S., Arru, A. P., \& Novani, S. (2015). Understanding Consumer Decisionmaking in Tourism Sector: Conjoint Analysis. Procedia - Social and Behavioral Sciences, 169(August 2014), 312-317. https:/ / doi.org/10.1016/j.sbspro.2015.01.315

Pizam, A., \& Fleischer, A. (2002). Severity versus frequency of acts of terrorism: Which has a larger impact on tourism demand? Journal of Travel Research, 40(3), 337-339. https:// doi.org/10.1177/0047287502040003011

Pitana, I GededanPutu G. Gayatri. 2005. SosiologiPariwisata. Yogyakarta: CV Andi Offset.

Reichel, A., Fuchs, G., \& Uriely, N. (2007). Perceived risk and the noninstitutionalized tourist role: The case of Israeli student ex-backpackers. Journal of Travel Research, 46(2), 217-226. https:/ / doi.org/10.1177/0047287507299580

Reisinger, Y., \& Mavondo, F. (2005). Travel anxiety and intentions to travel internationally: Implications of travel risk perception. Journal of Travel Research, 43(3), 212-225. https:/ / doi.org/10.1177/0047287504272017

Rittichainuwat, B. N., \& Chakraborty, G. (2009). Perceived travel risks regarding terrorism and disease: The case of Thailand. Tourism Management, 30(3), 410418. https://doi.org/10.1016/j.tourman.2008.08.001

Rocklöv, J., Quam, M. B., Sudre, B., German, M., Kraemer, M. U. G., Brady, O., Bogoch, I. I., Liu-Helmersson, J., Wilder-Smith, A., Semenza, J. C., Ong, M., Aaslav, K. K., \& Khan, K. (2016). Assessing Seasonal Risks for the Introduction and Mosquito-borne Spread of Zika Virus in Europe. EBioMedicine, 9, 250-256. https://doi.org/10.1016/j.ebiom.2016.06.009

Seddighi, H. R., \& Theocharous, A. L. (2002). A model of tourism destination choice: A theoretical and empirical analysis. Tourism Management, 23(5), 475-487. https:/ / doi.org/10.1016/S0261-5177(02)00012-2

Suharno dan Yudi Sutarso. (2010). Marketing In Practice. Graha Ilmu.

Suryani, T. (2008). Perilaku Konsumen Implikasi Pada Strategi Pemasaran. Graha Ilmu. Suwarduki, P., Yulianto, E., \& Mawardi, M. (2016). Pengaruh Electronic Word Of

Mouth Terhadap Citra Destinasi Serta Dampaknya Pada Minat Dan Keputusan Berkunjung (Survei pada Followers Aktif Akun Instagram Indtravel yang Telah Mengunjungi Destinasi Wisata di Indonesia). Jurnal Administrasi Bisnis S1 Universitas Brawijaya, 37(2), 1-10.

Swastha, BasuDharmmestadan T. Hani Handoko. 2000. ManajemenPemasaran, AnalisaPerilakuKonsumen. Yogyakarta: BPFE-Yogyakarta.

Tavitiyaman, P., \& Qu, H. (2013). Destination Image and Behavior Intention of 
Travelers to Thailand: The Moderating Effect of Perceived Risk. Journal of Travel and Tourism Marketing, 30(3), 169-185. https:// doi.org/10.1080/10548408.2013.774911

Tasci, D.A danKozak, M. 2006. Destination Brands vs Destination Image: Do We Know What We Mean? Journal of Vacation Marketing. Utama,

Tjiptono, F. (2008). Strategi Pemasaran (Edisi Keti). CV Andi Offset.

Weber, K., \& Roehl, W. S. (2001). Service Quality Issues for Convention and Visitor Bureaus. Journal of Convention \& Exhibition Management, 3(1), 1-19. https://doi.org/10.1300/j143v03n01_01

WHO. (2021). Coronavirus disease (COVID-19) pandemic. WHO. https://www.who.int/emergencies/diseases/novel-coronavirus-2019 